\title{
Synodality - Participation - Co-Responsibility Remarks on the Determinants of the Aggiornamento of Church Law
}

\begin{abstract}
In the communio Ecclesiae reality, of a unitarian, charismatic, and institutional structure, the crucial concepts of participation and co-responsibility are firmly anchored in the juridical and canonical discourse. This is the way in which the horizon of the subject matter reveals itself, the study of which - from the point of view of the title triad: synodality - participation - co-responsibility - will never lose its relevance. What is, at the same time, important is the idea of "synodality," which is adequately recognized as the sacra potestas of a sacramental origin (ontological aspect), which gains the dynamism of libertas sacra (existential and dynamic aspect) through the charisms of the Holy Spirit, thus leading to the inseparability of its personal and synodal aspects.

Therefore, in the attempt to illuminate the determinant of the aggiornamento of the Church law in this study, it was appropriate, on the one hand, to consistently refer to the essence of the idea of the communio hierarchica, according to which Christ makes selected servants participate in his authority by means of an office, the exercise of which always remains a diaconia in the community of faith. On the other hand, in reference to the contemporary understanding of communio fidelium, the axis of scientific reflection was to be the communion-creative phenomenon of charisms - gifts of the Holy Spirit that awaken in the People of God synodal co-responsibility for the good of the entire Church community. In both cases - without losing sight of the obvious truth that, in the sacramental structure of the Church (communio), both hierarchical and charismatic gifts converge in the service of the bishop, who updates - according to the logic of the Vaticanum II aggiormamento and the ecclesiological principles of the Council: collegiality, the title synodality and subsidiarity — the fullness of Christ's service: as Prophet, Priest, and King.
\end{abstract}

Keywords: ecclesiology, communio principle, synodality, participation, co-responsibility, aggiornamento of Church law 


\section{The context of the communio principle}

"The ecclesiology of the community (communio) is the central and fundamental idea of the documents of the Council" known stance that was formulated in 1985 at the Extraordinary Assembly of the Synod of Bishops, which "programmatically" summarised the twenty-year period after the Second Vatican Council. It is not difficult to guess that such a categorically formulated synodal message reverberated in the circles of theologians and canonists at the time. The representative voice of the former should be associated with the opinion that was issued by the Prefect of the Congregation for the Doctrine of the Faith, Cardinal Joseph Ratzinger, who did not fail to emphasise his contribution to the promotion of this idea: a drive prevails - the future pope would claim - "to sum up conciliar ecclesiology in a basic concept: the ecclesiology of communio. I received this new focus of ecclesiology with joy and did my best to prepare it. [...] The word communio does not have a central position in the Council. But if it is properly understood it can serve as a synthesis for the essential elements of conciliar ecclesiology."2

No less fertile ground did the Roman declaration find in the canonists' circles, especially in the circle of Klaus Mörsdorf's ${ }^{3}$ students. One of the contemporary continuators of the thoughts of the founder of the Munich school, the former rector of Gregorian University, Gianfranco Ghirland, considers the stance of the Synod Fathers to be consistent with the teachings of Pope Paul VI, who has always seen ius communionis ${ }^{4}$ in the Church law. According to the Italian canonist, the fact that the ecclesiology of community constitutes the basis of the order in the Church is best evidenced by the fact that Church law, in its positive and human dimension, has a redemptive value. Indeed, it can easily be defined as ius sacrum the expression and instrument of implementing God's law (revealed and natural) with all of its immanent "dynamics" of creating the development of the Church community hic et nunc. ${ }^{5}$ How, in practice, can the potential

${ }^{1}$ Synod of BIsHops: Second Extraordinary General Assembly: Ecclesia sub Verbo mysteria Christi celebrans pro salute mundi. Relatio finalis [7.12.1985], II, C, 1. Enchiridion Vaticanum, 9/1800.

2 J. Ratzinger: The Ecclesiology of the Constitution of the Church, Vatican II, Lumen Gentium [27.02.2000]. Available online at: http://www.ewtn.com/library/curia/cdfeccl. htm (accessed 15.12.2018).

3 See e.g. O. SAIER: „Communio” in der Lehre des Zweiten Vatikanischen Konzils. Eine rechtsbegriffliche Untersuchung. München 1973.

${ }^{4}$ G. GHIRLANDA: Introduzione al diritto ecclesiale. Lineamenti per una teologia del diritto nella Chiesa. Roma 20132, p. 147.

5 Ibidem, p. 40. 
of the Ecclesia iuris ${ }^{6}$ defined in such a way be identified? Professor Ghirland's answer to this question is already signalled by the very title of the fifth and final chapter La "communio" regola dell'organizzazione del popolo di Dio of the well-known book Introduzione al diritto ecclesiale... (1993). ${ }^{7}$ After the introductory section 5.1: La comunione, un pricipio non espresso, very meaningful section titles start to appear: 5.2. Comunione dei fedeli comunione tra le chiese, 5.3. Comunione ecclesiastica - comunione cattolica, 5.4. Comunione gerarchica, 5.5. Carità e comunione ecclesiale, 5.6. Comunione - corresponsabilità - partecipazione. As we can see, in the communio Ecclesiae reality, which structure is both unitarian ${ }^{8}$ and charismatic-institutional, the crucial concepts of participation and co-responsibility are firmly anchored in the juridical-canonical discourse.

It is worth risking a statement that this is the way in which the horizon of the subject matter reveals itself, the study of which - from the point of view of the title triad: synodality - participation - co-responsibility will never lose its relevance. What is, at the same time, important is the idea of "synodality," which is adequately recognised as the sacra potestas of a sacramental origin (ontological aspect), ${ }^{9}$ which gains the dynamism of libertas sacra (existential-dynamic aspect ${ }^{10}$ ) through the charisms of the Holy Spirit, thus leading to the inseparability of its personal and synodal aspects. ${ }^{11}$ Therefore, in the attempt to illuminate the determinant of the

${ }^{6}$ Cf. A. Pastwa: "Libertas religiosa w kościelnym porządku prawnym.” In: "Reddite ergo, quae sunt Caesaris, Caesari et, quae sunt Dei Deo". Ksiega jubileuszowa dedykowana Księdzu Profesorowi Józefowi Krukowskiemu z okazji 50-lecia pracy naukowej. Eds. M. Sitarz, P. Stanisz, H. Stawniak. Lublin 2014, pp. 180-189.

7 G. Ghirlanda: Introduzione al diritto ecclesiale..., pp. 147-198.

8 See W. Aymans: "Die communio Ecclesiarum als Gestaltgesetz der einen Kirche." Archiv für Katholisches Kirchenrecht 139 (1970), pp. 69-90; see also U. NAVARrete: "Unità della 'potestas sacra' e moltiplicità dei 'munera'." In: Der Staat der Vatikanstadt, der Heilige Stuhl und die Römische Kurie. Ed. W. Schulz. Frankfurt am Main 1999, pp. 361-389.

9 Cf. P. KräMER: "Su cosa si fonda la 'potestas sacra'?" In: Antropologia, fede $e$ diritto ecclesiale. Atti del Simposio Internazionale sugli studi canonistici di Eugenio Corecco (Lugano, 12 novembre 1994). Ed. L. Gerosa. Milano 1995, pp. 45-56; see more P. KRÄMER: Dienst und Vollmacht in der Kirche. Eine rechtstheologische Untersuchung zur Sacra Potestas-Lehre des II. Vatikanischen Konzils [Trierer Theologisches Studien, vol. 28]. Trier 1973.

${ }^{10}$ Cf. W. Aymans: "Kirchliche Grundrechte und Menschenrechte." Archiv für katholisches Kirchenrecht 149 (1980), p. 405.

${ }^{11}$ See E. CoRecco: "Sinodalità e partecipazione nell'esercizio della 'potestas sacra'." In: Esercizio del potere e prassi della consultazione. Atti dell'VIII Colloquio internazionale romanistico-canonistico (10-12 maggio 1990). Eds. A. Ciani, G. Diurni. Città del Vaticano 1991, pp. 69-89; L. Gerosa: "Vollmacht und Gemeinschaft in der Kirche." In: Krönung oder Entwertung des Konzils? Das Verfassungsrecht der katholischen Kirche im Spiegel der Ekklesiologie des Zweiten Vatikanischen Konzils. Eds. S. Demel, L. Müller. 
aggiornamento of the Church law that is undertaken here, it is appropriate, on the one hand, to consistently refer to the essence of the idea of the communio hierarchica, according to which Christ makes selected servants of His (especially clergyman, but not exclusively) participate in His authority by means of an office, the exercise of which always remains a diaconia in the community of faith. On the other hand, in reference to the contemporary understanding of communio fidelium, the axis of scientific reflection should be the communion-creative phenomenon of charisms - gifts of the Holy Spirit that awaken in the People of God synodal co-responsibility for the good of the entire Church community. In both cases - without losing sight of the obvious truth that in the sacramental structure of the Church (communio), both hierarchical and charismatic gifts converge in the service of the bishop, ${ }^{12}$ who updates - according to the logic of the Vaticanum II aggiormamento and the ecclesiological principles of the Council: collegiality ${ }_{13}^{13}$ the title synodality and subsidiarity $^{14}$ - the fullness of Christ's service: as Prophet, Priest, and King (trio munera Christi).

\section{Aggiornamento - the Christological dimension of the Church community's mission}

Twenty years have passed since the publication of the famous text "The unchangeability and historicity of the law in the Church: God's law and human law," 15 in which Professor Remigiusz Sobański inscribed himself intentionally ${ }^{16}$ into the then open discussion of the theologians and theoreticians of the Church law. The outstanding Polish scholar joined an excellent circle of canonists who, in their scientific reflection, addressed one of the most important topics of the study of canon law in the second

Trier 2007, pp. 39-55; L. GERosA: "Rechtstheologische Grundlagen der Synodalität in der Kirche. Einleitende Erwägungen.” In: Iuri Canonici Promovendo. Festschrift für Heribert Schmitz. Eds. W. Aymans, K.-Th. Geringer. Regensburg 1994, pp. 35-55.

12 Cf. A. Pastwa: "Sensus fidei fidelium. Legal and Ecumenical Reflection." Ecumeny and Law 6 (2018), pp. 229-230.

${ }^{13}$ See G. Mazzoni: La collegialità tra teologia e diritto canonico. Bologna 1986.

14 See P.-S. Freiling: Das Subsidiaritätsprinzip im kirchlichen Recht [Beihefte zum Münsterischen Kommentar, vol. 13]. Essen 1995.

15 R. Sobański: “Niezmienność i historyczność prawa w Kościele: prawo Boże i prawo ludzkie." Prawo Kanoniczne 40 (1997) 1-2, pp. 23-44.

16 Ibidem, p. 24. 
half of the 20th century. ${ }^{17}$ It is not difficult to notice that the ideological keystone of the author's reflections, which are included in the said text that shed light on the central "problem of "God's law"'18 is a still timely requirement for the renewal of Church law. What is connected with this requirement is the consistent attempt "today and tomorrow" to face the challenge of having a dynamic/concrete reception of Revelation ${ }^{19}$ (in the form of data content and hic et nunc messages that are to be transmitted as judicial or at least as juridical ${ }^{20}$ ). This is all to make sure that "the new canonical legislation will prove to be an efficacious means" ${ }^{21}$ of the People of God's mission, which is active undertaking of responsibility for the evangelical testimony of delivering the revealed truth. It is about a challenge - we should add - the addressee of which is the entire ${ }^{22}$ Church community.

As Remigiusz Sobański accurately states, the question of understanding the legal character of God's law, namely, the creative presence of God's law in Church law, turns out to be pivotal in updating such a legal-pastoral vision of the understanding of Revelation. Apart from the affirmation of the elementary truth that this latter law — perceived according to the blueprint of the "renewal in continuity" hermeneutics - consists of changeable and unchangeable, divine and human elements, ${ }^{23}$ we should also draw conclusions from the seemingly obvious and, it would seem, not really meaningful fact that the ius divinum carries with it an element

17 See S. Berlingò: "Diritto divino e diritto umano nella Chiesa." In: Diritto "per valori" e ordinamento costituzionale della Chiesa. Giornate canonistiche di studio Venezia, 6-7 VII 1994. Eds. R. Bertolino, S. Gherro, G. Lo Castro. Torino 1996, pp. 87-116 (the same - in: "Il diritto ecclesiastico" 106 /1995/ I, pp. 35-65); H. PreE: "Zur Wandelbarkeit und Unwandelbarkeit des Ius Divinum." In: Theologia et ius canonicum. Festgabe für Heribert Heinemann zur Vollendung seines 70. Lebensjahres. Ed. H.J.F. REINHARDT. Essen 1995, pp. 111-135; I. Riedel-SPANGENBERgER: "Gottesrecht und Menschenrecht. Zur Legitimation, Limitation und Normierung positiven kirchlichen Rechts." In: Theologia et ius canonicum..., pp. 99-109.

${ }^{18}$ R. SobAŃski: “Niezmienność i historyczność prawa...,” pp. 25-32.

19 Cf. H. Pree: "Zur Wandelbarkeit und Unwandelbarkeit des Ius Divinum...," p. 123.

${ }^{20}$ R. Sobański: "Niezmienność i historyczność prawa...," p. 25.

${ }^{21}$ John Paul II: Apostolic Constitution Sacrae disciplinae leges [25.01.1983]. http://w2.vatican.va/content/john-paul-ii/en/apost_constitutions/documents/hf_jp-ii_ apc_25011983_sacrae-disciplinae-leges.html (accessed 15.12.2018).

${ }^{22}$ Indeed, it is, first and foremost, the task of a pope and bishop, who through Christ's will serve as legislators, however, forgetting about the part that is played by all of the faithful would be an evident shortening of the theological and legal perspective. This will be the topic of further remarks.

${ }^{23}$ As Remigiusz Sobański notes, the problem God's law - people's law is invariably present in the history of law. The author explains: "among the idea determinants of this problem, the very understanding of law is of a paramount importance." R. SobAŃskI: "Niezmienność i historyczność prawa...," p. 26. 
of mystery. ${ }^{24}$ This is an "obvious" fact only until we realise that this element of mystery, which is "anchored" in the Trinitatis mysterium (and consequently, in the mysterium Ecclesiae), determines that the quid ius proprie divinum problem as well as the quid ius proprie humanum cannot be solved universally, "once and for all." Therefore, instead of taking the view (still representative in the $1960 \mathrm{~s}^{25}$ ) that the reservoir of faith contains legal norms that simply need to be read, understood, defined, and communicated without reflection, it is appropriate, when reflecting upon the phenomenon of Church law (and God's law that is contained in it), to consider at least three premises in the name of conciliar fidelity to the Council's aggiornamento: (1) the ecclesiological premise: in the Churchmystery, the visible element, together with the law of which it is composed, is an operative sign and expression of grace ("social incorporation of grace" 26$)$; (2) the Christological premise: in every attempt to illuminate the process of transforming the revealed truth into law, only faith offers protection against its static, positivist understanding; faith which in Jesus Christ sees the Giver of ius divinum, ${ }^{27}$ and (3) the anthropological (personalistic) premise: since Christ's revelation of the truth about the human person is the main reference point of what the Church perceives to be God's law, ${ }^{28}$ the affirmation of the salus animarum, the systemic principle of all legislation, means that the finalism of ius Ecclesiae, which is defined in this way, is the fundamental vector for any identification of the hic et nunc content: both subjective rights and the welfare of individuals as well as the welfare of society as a whole. ${ }^{29}$

It is safe to argue that in the face of the fundamental question of quid ius,$^{30}$ all three premises - including the fundamental principle of the Church juridical order salus animarum - refer us to the common good as understood personalistically. ${ }^{31}$ Its reading, if we are to use the highly

${ }^{24}$ R. Bertolino: Il nuovo diritto ecclesiale tra coscienza dell'uomo e istituzione. Saggi di diritto costituzionale canonico. Torino 1989, p. 14.

${ }^{25}$ See e.g. G. MAY: "Die Kontinuität im kanonischen Recht.” Archiv für katholisches Kirchenrecht 135 (1966), pp. 52-92.

${ }^{26}$ R. Sobański: "Niezmienność i historyczność prawa...," p. 42.

${ }^{27}$ Cf. ibidem, p. 43.

${ }^{28}$ Cf. ibidem, p. 28.

29 Cf. Z. Grocholewski: “Specyfika prawa Kościoła katolickiego. Referat wygłoszony z okazji otrzymania tytułu doktora honoris causa Uniwersytetu im. Adama Mickiewicza w Poznaniu, dnia 7 maja 2004." Poznańskie Studia Teologiczne 17 (2004), p. 26. “The objective of canon law is [...] to create special conditions and to guarantee the necessary help to make sure man can achieve his goal in the eternal perspective." Ibidem.

30 See T. GaŁкоwsкi: Il "quid ius" nella realtà umana e nella Chiesa. Roma 1996.

${ }^{31}$ We do not really need to prove that while redemption is a transcendent goal, the earthly goal, which is defined by the salus animarum principle, is to build a divine- 
instructive teachings of the popes, the theologian of law Paul $\mathrm{VI}^{32}$ and the philosopher of law John Paul II, ${ }^{33}$ determines two complementary perspectives. The first one, which responds to the contemporary understanding of law as an order of freedom ${ }^{34}$ and an instrument for the promotion of human rights, places the original legal system based on a new (renewed by Christ) justice ${ }^{35}$ as the centre of attention - with a clear message, addressed primarily to shepherds, united in communio hierarchica: building within the framework of pastoral care (cura pastoralis) ${ }^{36}$ the bonds of solidarity and community. ${ }^{37}$

The second perspective, on the other hand, tells us to take the paradigm of the Church as our starting point - the sacramental-charismatic communio fidelium, the common good of which is the law, which is perceived as the order of sanctification, coupled with the mission (missio) $)^{38}$

human communio. Hence, the common good occupies a primary place in the juridical thought of the Church

32 Cf. M. Graulich: Unterwegs zu einer Theologie des Kirchenrechts: die Grundlegung des Rechts bei Gottlieb Söhngen (1892-1971) und die Konzepte der neueren Kirchenrechtswissenschaft. Paderborn-München-Wien-Zürich 2006, pp. 196-209; see also R. Marangoni: La Chiesa, mistero di comunione. Il contributo di Paolo VI nell'elaborazione dell'ecclesiologia di comunione (1963-1978). Roma 2001.

33 See Z. Grocholewski: La filosofia del diritto di Giovanni Paolo II. Roma 2002.

34 Cf. A. Pastwa: "The Law of the Church - the Law of Freedom." Ecumeny and Law 4 (2016), pp. 105-125.

35 Cf. A. PAstwa: „Przymierze miłości matżeńskiej”. Jana Pawła II idea małżeństwa kanonicznego. Katowice 2009, pp. 205-208.

36 "Beim II. Vatikanischen Konzil greift man auf die genuin theologische und pastorale Bedeutung der Diözese zurück und bestimmt diese als eine Gemeinde von Gläubigen, zu der ein bestimmter Kreis des Gottesvolkes gehört, dessen Bestimmung (determinatio) davon abhängt, dass die höchste kirchliche Autorität der cura pastoralis eines Bischofs einen Kreis von Gläubigen zuweist, d. h. anvertraut. Diese Gläubigen sind auf einen Diözesanbischof hingeordnet, dem unmittelbar in der Nachfolge der Sendung und Vollmacht des Zwölferkreises der Apostel die Gläubigen zum persönlichen und primär pastoralen Dienst (munus pastorale) mit der dazu notwendigen geistlichen Vollmacht (sacra potestas) zur Hirtensorge (cura pastoralis) anvertraut sind. Die spezifische Bestimmung und Aufgabe der Diözesanbischöfe ist es, für die ihm anvertrauten Gläubigen, durch Verkündigung (munus docendi), Heiligung (munus sanctificandi) und Leitung (munus regendi), d. h. für alle diese drei Bereiche (tria munera) zusammen, das umfassende "munus pastorale“ (= cura pastoralis bzw. plena cura animarum) auszuüben.” I. Riedel-Spangenberger: "Ortskirche oder Teilkirche? Das vom Bischof geleitete Volk Gottes der Diözese." In: Rechtskultur in der Diözese. Grundlagen und Perspektiven. Ed. EAdEM. Freiburg im Breisgau 2006, pp. 17-18.

37 John PaUl II: Allocutio ad Rotae Romanae Praelatos, auditores, officiales et advocatos anno iudiciali ineunte [18.01.1990]. AAS 82 (1990), p. 874, n. 4.

38 "Die Sendung Jesu Christi (missio divina), die er den Aposteln anvertraut hat (missio apostolica) lebt in der Kirche fort und stellt die Grundlage dafür dar, dass die Kirche 'Zeichen und Werkzeug für die innigste Vereinigung mit Gott wie für die Einheit der 
that was entrusted to the Church. Inspired by the Holy Spirit, the whole priestly People of God and their individual members are called, in accordance with the principles of co-responsibility and co-participation, to build the Body of Christ through the living testimony of faith and active participation in the expansion and strengthening of the grace of redemption.

We are permitted to ask what the potential of the aggiornamento is the renewal of the Church law - in the context of the much-desired dynamics of the realisation of the personal common good in communionem, in which the aforementioned optics of the perception of the ius Ecclesiae are hidden.

The first perspective is defined by the pastoral service of the Church legislator (munus legislatoris) for the People of God that is carried out in a hierarchical community. ${ }^{39}$ The will of the Highest Legislator is the catalyst for renewal: "bringing into reality the order of intra-ecclesial justice willed by Christ himself." 40 The "revitalised" (optimally: with the implementation of the instruments of synodal participation) segments of the original juridical system in the legislative service of shepherd will always refer to the novum of a redemptive perspective, which is about the higher justice that is embedded in the Triune God and as such has been revealed by Christ, with Christ and in Christ and which goes far beyond the concept of "purely human" justice - the work of the genius of humanistic thought that is present in Greek philosophy and Roman law with the fundamental principle: suum cuique tribuere. ${ }^{41}$ What is worth emphasising is that evangelical justice demands more than mere respect for the law in intersubjective relationships.

Since we must remember, as Paul VI explained in his famous speech at the Second International Congress of Canon Law in Rome in 1973,42 that the rights and obligations of the followers have their supernatural source in the relationship of God (the Trinity of the Divine Persons) to man (the person endowed with the dignity and freedom of the child of

ganzen Menschheit' sein kann. Jeder Gläubige ist auf Grund von Taufe und Firmung entsprechend seinem Stand dazu berufen, an der Erfüllung dieser Sendung mitzuarbeiten.” M. Graulich: "Hirtensorge in umfassender Verantwortung. Dienst des Diözesanbischofs in Verkündigung, Heiligung und Leitung." In: Rechtskultur in der Diözese..., p. 163.

39 Cf. Vatican Council II: Dogmatic Constitution on the Church Lumen gentium [21.11.1964], n. 21.

40 John Paul II: Allocutio ad Rotae Romanae Praelatos, auditores, officiales et advocatos anno iudiciali ineunte [18.01.1990], p. 874, n. 4.

${ }^{41}$ Ulpian defines justice in the following way: Iustitia est constans et perpetua voluntas ius suum cuique tribuens. D,1,1,10.

42 Paul VI: Allocutio. Iis qui interfuerunt II Congressui Associationis Internationalis Canonistarum Mediolani habito [17.09.1973]. Communicationes 5 (1973), pp. 125-130. 
God) and in such a constitutionalised order of the structures of justice, ${ }^{43}$ they remain in the service of redemption, in the service of the common good and in the service of the salus animarum. ${ }^{44}$ In the Church's legal system, there is, therefore, no place for a utilitarian (individualistic rather than truly personalistic ${ }^{45}$ ) exercise of rights and freedoms, the defence of particular interests and the ignorance of the rights/good of others. ${ }^{46}$ The essence of the realisation of the christianae iustitiae is to build a community of believers in which everyone recognises themselves as brothers and sisters, children of one God. ${ }^{47}$

Evangelical righteousness, which is the revelation of the redemptive righteousness-love of God, leads the members of the Mystical Body of Christ to unity. The dynamics of this process - the justification and gift per Christum et cum Christo et in Christo - is governed by the rules of communion and solidarity.

This ius Ecclesiae vision is complemented by John Paul II, who was the author of valuable depictions of the Veritatis splendor encyclical to show the applications of the Christological paradigm. ${ }^{48}$ In his 1994 Address to the Roman Rota, the Pope, when referring to the teaching of this longest-prepared, and perhaps, most important document of his pontificate, emphasises the close relationship between splendor veritatis and splendor iustitae, and what is also important, refers this regularity to the entire

${ }^{43}$ Ibidem, p. 124, n. 1.

44 "I diritti e i doveri nella Chiesa hanno un'indole soprannaturale: se la Chiesa è un disegno divino - Ecclesia de Trinitate - le sue istituzioni, pur perfettibili, devono essere stabilite al fine di comunicare la grazia divina e favorire, secondo i doni e la missione di ciascuno, il bene dei fedeli, scopo essenziale della Chiesa. Tale scopo sociale, la salvezza delle anime, la 'salus animarum', resta lo scopo supremo delle istituzioni, del diritto, delle leggi. Il bene comune della Chiesa raggiunge perciò un mistero divino, quello della vita della grazia, che tutti i cristiani, chiamati ad essere figli di Dio, vivono nella partecipazione alla vita trinitaria: Ecclesia in Trinitate. In questo senso il Concilio Vaticano II ha parlato della Chiesa anche come 'comunione' (Cfr. Lumen Gentium, 4, 9, 13, etc.), ponendo così in luce il fondamento spirituale del Diritto nella Chiesa e la sua ordinazione alla salvezza dell'uomo: sicché il Diritto diventa Diritto di carità in questa struttura di comunione e di grazia per tutto intero il Corpo ecclesiale." Ibidem, pp. 126-127, n. 2.

45 John Paul II: Letter to Families "Gratissimam Sane" [2.02.1994], n. 14.

${ }^{46}$ CIC 1983, can. 223: "In exercising their rights, Christ's faithful, both individually and in associations, must take account of the common good of the Church, as well as the rights of others and their own duties to others $(\S 1)$. Ecclesiastical authority is entitled to regulate, in view of the common good, the exercise of rights which are proper to Christ's faithful (\$2)."

${ }^{47}$ See Paul VI: Allocutio ad Tribunalis Sacrae Romanae Rotae Decanum, Praelatos Auditores, Officiales et Advocatos, novo Litibus Iudicandis ineunte anno, de protectione iustitiae perfectiore reddenda [4.02.1977]. AAS 69 (1977), pp. 147-153.

48 John PAul II: Encyclical letter "Veritatis splendor" [6.08.1993]. 
Church legal order. ${ }^{49}$ What, in fact, is this original appendix to the theology of ecclesiastical law by the great teacher of personalism? ${ }^{50}$ Based on the synthesis of the said magisterial presentation, in the Catechism of the Catholic Church, on the virtue of justice - as one which "disposes one to respect the rights of each and to establish in human relationships the harmony that promotes equity with regard to persons and [realisation of - A.P.] the common good" 51 - then in this very context the in carita$t a e^{52}$ rule of the continuous updating of truth reveals its legal profile to the fullest. This ius Ecclesiae axiom, which is immanent in the system, constitutes invariably — yesterday and today - the only durable foundation on which personal, family, and social life is based." 53

This is how the previously mentioned thesis of Remigiusz Sobański is verified. The repeatedly undertaken reflection of the Shepherds of the Church on the "shape" of the ius divinum ius ecclesiasticum relationship in connection with the realisation of the munus legislatoris: in the service of the people of God who are under their pastoral care (cura pastoralis in caritatae), ${ }^{54}$ should mean a constant confrontation with the question: How the truth that Church law in communication with different (synchronically and diachronically) juridical cultures should never lose its own proprium, but should faithfully expose it is to be understood? ${ }^{55}$ The hint from the eminent canonist is thought-provoking: "Between Passover and parousia, in other words, in the time during which Jesus Christ is the centre, fullness and ordering principle, this fidelity is the aggiornamento, that is, making the Church 'contemporary' as the leavening of this world. This renewal is a continuous task and the Church community is committed to a lasting renewal of fidelity to its origins and mission, taking into account the changing social and cultural circumstances in which the Church has to act." ${ }^{56}$

${ }^{49}$ John Paul II: Allocutio Summi Pontificis ad Iudices, Administros Advocatosque Rotae Romanae coram admissos [28.01.1994]. AAS 86 (1994), p. 948, n. 2.

${ }^{50}$ Cf. A. Pastwa: „Przymierze miłości małżeńskiej”..., pp. 21-110.

${ }^{51}$ Catechism of the Catholic Church [11.10.1992], n. 1807. Available online at: http:// www.vatican.va/archive/ENG0015/_INDEX.HTM (accessed 15.12.2018).

52 John Paul II: Allocutio Summi Pontificis ad Iudices, Administros Advocatosque Rotae Romanae coram admissos [28.01.1994], pp. 948-949, n. 2-3; see G. GHIRLANDA: "La carità come principio giuridico fondamentale constitutivo del diritto Ecclesiale." La Civiltà Cattolica 128 (1977), II, pp. 454-471.

53 John PAul II: Allocutio ad Rotae Romanae Praelatos, auditores, officiales et advocatos anno iudiciali ineunte [18.01.1990], p. 875, n. 5.

${ }^{54}$ M. WiJlens: "Gesetzgebung für das Volk Gottes. Vollmacht und Auftrag des Diözesanbischofs.” In: Rechtskultur in der Diözese..., pp. 258-268.

${ }_{55}$ R. Sobański: "Niezmienność i historyczność prawa...," p. 42.

${ }^{56}$ Ibidem, p. 44. 


\section{Aggiornamento - the pneumatological dimension of the Church community's mission}

Is canon law synodal law? - this rhetorical question, which Professor Libero Gerosa ${ }^{57}$ introduced to the canonist debate in 1994, can be treated as a kind of scholarly manifesto - an appeal to promote the idea of ius communionis in the entire Church. It was then - just like today - about making sure that the shape of the law-making processes in the Church is determined by the specificity (proprium) of Church law - with the immanently inscribed renewal potential in it, thereby making the Church "contemporary," according to the principle of the Sacrae disciplinae leges Constitution: "fidelity in newness and of newness in fidelity." 58 This was the vision of ius Ecclesiae that John XXIII observed when he announced the convening of the Roman Synod and the Second Vatican Council in 1959, when, as is written in the Praephatio to the Code of Canon Law (1983), the Pope "declared that these events would inevitably be preparation for the renewal of [the said collection - A.P.]." 59 This view of the Canones is represented by the final fragment of the Praefatio, which is worth quoting in extenso: "If, however, because of the too rapid changes in contemporary human society, certain things have already become less perfect at the time of the law making and will consequently require a new revision, the Church is equipped with such a strength that, as in the past centuries, it will be able to find a way to renew the law of its own life." ${ }^{60}$ It is worth emphasising, once again, that the aim here is the task of the whole Church community "here and now": faithfulness to God's law in the face of the changing signs of the time ${ }^{61}$; faithfulness that is based, above all, on the sense of faith (sensus fidei), which is awakened and sustained by the Holy Spirit, faithfulness without which the Church would lose its identity. ${ }^{62}$ Already at this point, we can see the important role that the integral reception of the Council's ecclesiology has to play in understanding the meaning of the systematic revision/revitalisation of the norms of the ius communionis in the name of a more complete updating of the person-centric common good (salus animarum).

${ }^{57}$ L. Gerosa: "Rechtstheologische Grundlagen Synodalität...," p. 202.

58 John Paul II: Apostolic Constitution "Sacrae disciplinae leges" [25.01.1983].

59 John Paul II: Codex Iuris Canonici. Praefatio. AAS 75 (1983) II, p. XIX.

${ }^{60}$ Ibidem, p. XXX.

${ }^{61}$ Cf. International Theological Commission: Theology today: perspectives, principles and criteria (2011), nn. 51-58 - http://www.vatican.va/roman_curia/congregations /cfaith/cti_documents/rc_cti_doc_20111129_teologia-oggi_en.html [accessed: 15.12.2018].

${ }^{62}$ R. Sobański: "Niezmienność i historyczność prawa...," p. 44. 
If today, half a century after Vaticanum II, the statement that this "renewed" reflection on the current canonical regulations - whether in terms of their praxeological compatibility and functional interrelationships or in the no less important sphere of the subjective reception of law - should not be separated from the ecclesiological foundation, seems to be a truism, then a reminder in the context of the title aggiornamento that this foundation consists of - equally relevant (!) - Christological and pneumatological elements, turns out to be a perception of a special significance.

This issue has been categorically worded by Sabine Demel in the famous memento ${ }^{63}$ about "new accents" ${ }^{64}$ of the Council's magisterium on the common priesthood and the sensus fidei fidelium, still underestimated and awaiting proper resonance in the Church's praxis. The German canonist is right when she combines this ecclesiological paradigm - rightly associated with the emphasis on the pneumatological aspects of the Church as well as the Christological aspects in the most important document of the Council, the dogmatic constitution Lumen gentium - with the leading conciliar idea of a common priesthood of all the faithful. This is due, on the one hand, to the presentation of the role of the Holy Spirit that gives extraordinary and ordinary charismatic gifts (alongside hierarchical gifts), and, on the other hand, to the presentation of the dynamics of the testimony of the faith of the people of God, who are permanently "open" to the influence of the Spirit and the "signs of the time." Indeed, it is only the reference to the model of the Church of the "People of God," 65 strongly emphasised in Lumen gentium, and the related idea of the sensus fidei fidelium and of the equality of all of the faithful, that provides an opportunity for the proper inter-

${ }^{63}$ Such is the character of the text included in Herder Korrespondenz - S. Demel: "Rechtstheologische Grundlagen Dringender Handlungsbedarf." Der Glaubenssinn des Gottesvolkes und seine rechtliche Umsetzung. Herder Korrespondenz 58 (2004), pp. 618-623.

${ }^{64}$ S. Demel: Mitmachen - Mitreden - Mitbestimmen. Grundlagen, Möglichkeiten und Grenzen in der katholischen Kirche. Regensburg 2001, pp. 19-28.

${ }^{65}$ See J. Ratzinger: The Ecclesiology of the Constitution of the Church... Indeed, the statement which suggests that under the name "People of God" the leading model of the Church is hidden is just. That is how the second chapter of the mentioned Dogmatic Constitution on the Church is entitled (nn. 9-17). Following the Constitution, the same title was given to the II book of the Code of Canon Law. We need to bear in mind that if the conciliar models of Church-mystery serve partial (from some point of view) understanding of her nature, then when taken into consideration together they help to bring the mystery nearer. Therefore, what is necessary in a theological and legal-canonical considerations is the juxtaposition of three models: "People of God," "Mystical Body of Christ," and "Fundamental Sacrament" with the communion principle. Cf. Z. GroCHOLEwsKi: Specyfika prawa Kościoła katolickiego..., p. 29. 
pretation of the sense of synodality. For the sake of clarity, it is about the synodal exercise of the potestas sacra within tria munera Christi, which is no different than with the implementation of a renewed ecclesiological thought. In the light of the latter, the common priesthood of all of the faithful is ontically and functionally superior to the ministerial priesthood of the ordained. ${ }^{66}$

The logic of the adopted assumptions - which is important to mention - suggests a way to relieve the tension in the Church and in its law between the "sphere" of community (here: protection of the community of faith, especially the authenticity of the means of redemption: word and sacrament) and the "sphere" of the individual (here: protection of the implementation of subjective laws ${ }^{67}$ - by adding value to the synodal dimension of the Church: the pneumatological-charismatic dimension, which is on par with the Christological-hierarchical dimension that still dominates the ontical-structural depictions of Ecclesiae et ius Ecclesiae. The two equally fundamental and ecclesiologically inseparable dimensions require equal theological-pastoral and juridical-pastoral applications. ${ }^{68}$

The suggested comments open a wider horizon for the practice of law, that is, they display the basis for its creation, interpretation, application, and observance. Indeed, the rule that at none of the mentioned stages of the legal practice of the Church can the modus iuridicus break away from its theological base is fully valid. Consequently, if in the Church-mystery the norms of law are to motivate the ecclesiologically recognised goal of building a community that is a sign and realisation of redemption, then the previously indicated correctness acquires a crucial meaning. The point is that ius divinum should really shape, in the spirit of the aggiornamento, the juridical system of a given community, namely, that the particular pro-

${ }^{66}$ Cf. E. Corecco: “Sinodalità e partecipazione...," p. 85. "Die Frage, die gestellt werden muss, lautet: [...] Ist die Hierarchie Grundlage der Gemeinschaft, so dass Gemeinschaft aus der Verbundenheit mit der Hierarchie und damit aus einem Rechtsverhältnis besteht? Oder ist die Gemeinschaft Grundlage der Hierarchie, so dass Hierarchie in der der Gemeinschaft eine Funktion erfüllt: sie steht in ihrem Dienst. Diese Alternative ist kein akademisches Problem. Im einen Fall steht die Hierarchie über allem, im anderen bildet sie einen Teil des Ganzen. Lumen gentium ist in Aufbau und Aussage eindeutig. Die Hierarchie ist Teil des Volkes Gottes und leistet in ihm ihren Dienst." E. KLINGER: "Die dogmatische Konstitution über die Kirche Lumen gentium." In: Vierzig Jahre II. Vatikanum. Zur Wirkungsgeschichte der Konzilstexte. Eds. F.X. Bischof, S. LeIMgruber. Würzburg 2004, p. 89.

${ }^{67}$ Cf. R. SoвAŃski: "Omnis institutio ecclesiasticarum legum ad salutem referenda sit animarum. Uwagi o zbawieniu dusz jako celu prawa kościelnego.” Ateneum Kapłańskie 134 (2000), pp. 212-213.

${ }^{68}$ S. Demel: "Dringender Handlungsbedarf...," p. 619. 
visions of this system should grow out of faith, serve the practice of faith, and as such, always express the rule of life of the Church community. Only faithfulness to such theological-legal assumptions on the part of a shepherd-legislator, and more broadly, of all of the members of the communio fidelium (e.g. the diocese), guarantees the protection of the law of the community against the danger of unconscious inertia or even deliberate omissions/deficiencies in the fulfillment of the title duty - the acceptance of the static shape of the legislation (as the "custodian" of fossilised structures) and/or its positivist deformation.

At this point, we can already ask about the personal source of the renewal of this law, which brings the richness of the original proprium into the universe legal culture, the law, the essence of which is the law of God. It is not difficult to guess that the dynamic assistance of the Holy Spirit constantly inspires priestly people to ensure that, owing to the sense of the faith of the whole people of God (sensus fidei fidelium), ${ }^{69}$ not only the Shepherds of the Church, but also all of the faithful express common concern and feel co-responsible for the shape of the ius communionis. Saint Thomas Aquinas called the law of the New Covenant the gift of the grace of the Holy Spirit to the faithful. ${ }^{70}$ That is why Rinaldo Bertolino $^{71}$ and Remigiusz Sobański ${ }^{72}$ are right when they connect the renewal of the law of the community, which is manifested in the full systemic interiorisation of the three greatest gifts-charisms: faith, hope, and love, with the Third Divine Person.

As the latter canonist rightly notes, if we assume the continuity of the aggiornamento processes that are inspired by the Holy Spirit: transformative and concretising, then in such an approach, and consistently: the (re)formation of the Church's legislation, the canon code and its equivalents in the particular law will manifest themselves not only as ordinatio fidei and ordinatio caritatis, but also as ordinatio spei, on the condition, however, that all of the people of the God remain faithful to the already revealed and continuously revealed will of the Saviour, who live in the hope that they will actively observe God's law and its absolute continuity throughout the history. ${ }^{73}$

${ }^{69}$ Cf. A. Pastwa: "Sensus fidei fidelium...," pp. 235-236.

${ }^{70}$ Cf. STh I-II, q. 106, a. 1.

${ }^{71}$ R. Bertolino: "Sensus fidei, Charismen und Recht im Volk Gottes." Archiv für katholisches Kirchenrecht 163 (1994), pp. 28-72.

72 R. Sobański: "Charisma et norma canonica." In: Ius in vita et in missione Ecclesiae. Acta symposii internationalis Iuris Canonici occurrente $X$ anniversario promulgationis Codicis Iuris Canonici diebus 19-24 aprilis 1993 in Civitate Vaticana celebrati. Città del Vaticano 1994, 75-90.

73 R. Sobański: “Niezmienność i historyczność prawa...," p. 43; cf. R. Bertolino: "Sensus fidei, Charismen und Recht ...," p. 43. 


\section{Final remarks}

"Led by the Holy Spirit, Mother Church unceasingly exhorts her sons to purify and renew themselves so that the sign of Christ can shine more brightly on the face of the Church" 74 - in such a way, in a graceful synthesis, the Council Fathers "define" the process of the aggiornamento of the Church community (communio) and its law (ius communionis), which continuously takes place in the Holy Spirit; a process, the dynamics and profile of which - synodal participation and co-responsibility - are determined by the dynamism of evangelisation. The fact that this is a universal mission (ad extra) is already testimony to the "renewing" way of the Church's presence in the world, including the dynamic shape of its legal culture (among others, under the influence of other juridical cultures). The commentary contained in the Gaudium et spes Constitution leaves no room for doubt: "For, from the beginning of her history [the Church - A.P.] has learned to express the message of Christ with the help of the ideas and terminology of various philosophers, and has tried to clarify it with their wisdom, too. Her purpose has been to adapt the Gospel to the grasp of all as well as to the needs of the learned, insofar as such was appropriate." 75

In such a mission of the entire Church and the task of a specific Church community to give hic et nunc testimony about "the power and truth of the Christian message," ${ }^{76}$ the determinant of adequate contemporary ecclesiology, the principle of "the salvation of souls the supreme law," plays a role that cannot be overestimated. It determines the telos of all of the contemporary activity of the Church, including the practice of law, from its enactment and interpretation to its observance and application. The meaning of the renewal of the Church norms (and institutions) is based on promoting the idea of human dignity, its vocation and eternal destiny, adapted to the environment, or on the creation of conditions for the authentic, synodal realisation of the common good - in a word, this implies the basic principle of the Church law salus animarum (systemic quintessence of ius divinum). In fact, as the first of the ten principles of the renewal of the Code of Canon Law, which was adopted at the Synod of Bishops in 1967, states, it is important "that [all - A.P.] faithful in

${ }^{74}$ Vatican Council II: Pastoral Constitution on the Church Gaudium et spes [7.12.1965] [further: GS], n. 43.

75 GS, n. 44.

${ }^{76}$ GS, n. 43. 
the Christian life should become partakers of the goods offered by the Church, which lead them to eternal redemption." 77

77 Pontificia Commissio Codici Iuris Canonici Recognoscendo: "Principia quae Codicis Iuris Canonici recognitionem dirigant.” Communicationes 2 (1969), p. 77.

\section{Bibliography}

Aymans W.: "Die communio Ecclesiarum als Gestaltgesetz der einen Kirche." Archiv für Katholisches Kirchenrecht 139 (1970), pp. 69-90.

Aymans W.: "Kirchliche Grundrechte und Menschenrechte.” Archiv für katholisches Kirchenrecht 149 (1980), pp. 389-409.

Aymans W.: Das synodale Element in der Kirchenverfassung [Münchener theologische Studien. Kanonistische Abteilung, vol. 30]. München 1970.

Benedictus XVI: Allocutio ad Tribunal Rotae Romanae in inauguratione Anni Iudicialis [27.01.2007]. Acta apostolicae Sedis 99 (2007), pp. 86-91.

Berlingò S.: "Diritto divino e diritto umano nella Chiesa." In: Diritto "per valori" $e$ ordinamento costituzionale della Chiesa. Giornate canonistiche di studio Venezia, 6-7 VII 1994. Eds. R. Bertolino, S. Gherro, G. Lo Castro. Torino 1996, pp. 87-116 (the same — in: “Il diritto ecclesiastico" 106 /1995/ I, pp. 35-65);

Berlingò S.: Giustizia e carità nell'economia della Chiesa. Contributi per una teoria generale del diritto canonico [Collana di Studi di Diritto Canonico ed Ecclesiastico. Sezione canonistica, 3]. Torino 1991.

Bertolino R.: Il nuovo diritto ecclesiale tra coscienza dell'uomo e istituzione. Saggi di diritto costituzionale canonico. Torino 1989, p. 14.

Bertolino R.: "Sensus fidei, Charismen und Recht im Volk Gottes." Archiv für katholisches Kirchenrecht 163 (1994), pp. 28-72.

Catechism of the Catholic Church [11.10.1992]. Available online at: http://www .vatican.va/archive/ENG0015/_INDEX.HTM (accessed: 15.12.2018).

Corecco E.: "Sinodalità." In: Nuovo dizionario di teologia. Eds. Barbaglio Giuseppe, Dianich Severino. Roma $1991^{6}$, pp. 1431-1456.

Corecco E.: "Sinodalità e partecipazione nell'esercizio della 'potestas sacra'." In: Esercizio del potere e prassi della consultazione. Atti dell'VIII Colloquio internazionale romanistico-canonistico (10-12 maggio 1990). Eds. CiAni AMERICO, Diurni Giovanni. Città del Vaticano 1991, pp. 69-89.

Demel S.: "Dringender Handlungsbedarf. Der Glaubenssinn des Gottesvolkes und seine rechtliche Umsetzung." Herder Korrespondenz 58 (2004), pp. 618-623.

Demel S.: Mitmachen - Mitreden - Mitbestimmen. Grundlagen, Möglichkeiten und Grenzen in der katholischen Kirche. Regensburg 2001. 
FreILING P.-S.: Das Subsidiaritätsprinzip im kirchlichen Recht [Beihefte zum Münsterischen Kommentar, vol. 13]. Essen 1995.

GAŁKOWSKi T.: Il “quid ius” nella realtà umana e nella Chiesa. Roma 1996.

Gerosa L.: "Rechtstheologische Grundlagen der Synodalität in der Kirche. Einleitende Erwägungen.” In: Iuri Canonici Promovendo. Festschrift für Heribert Schmitz. Eds. Aymans Winfried, Geringer Karl-Theodor. Regensburg 1994, pp. 35-55.

Gerosa L.: "Vollmacht und Gemeinschaft in der Kirche." In: Krönung oder Entwertung des Konzils? Das Verfassungsrecht der katholischen Kirche im Spiegel der Ekklesiologie des Zweiten Vatikanischen Konzils. Eds. DeMEL SAbine, Müller Ludger. Trier 2007, pp. 39-55.

GHIRLANDA G.: “La carità come principio giuridico fondamentale constitutivo del diritto Ecclesiale.” La Civiltà Cattolica 128 (1977), II, pp. 454-471.

Graulich M.: "Hirtensorge in umfassender Verantwortung. Dienst des Diözesanbischofs in Verkündigung, Heiligung und Leitung." In: Rechtskultur in der Diözese. Grundlagen und Perspektiven. Ed. Riedel-Spangenberger Ilona. Freiburg im Breisgau 2006, pp. 163-188.

Graulich M.: Unterwegs zu einer Theologie des Kirchenrechts: die Grundlegung des Rechts bei Gottlieb Söhngen (1892-1971) und die Konzepte der neueren Kirchenrechtswissenschaft. Paderborn-München-Wien-Zürich 2006.

Grocholewski Z.: La filosofia del diritto di Giovanni Paolo II. Roma 2002.

Grocholewski Z.: "Specyfika prawa Kościoła katolickiego. Referat wygłoszony z okazji otrzymania tytułu doktora honoris causa Uniwersytetu im. Adama Mickiewicza w Poznaniu, dnia 7 maja 2004." Poznańskie Studia Teologiczne 17 (2004), pp. 19-33.

International Theological Commission: Theology today: perspectives, principles and criteria (2011). http://www.vatican.va/roman_curia/congregations /cfaith/cti_documents/rc_cti_doc_20111129_teologia-oggi_en.html (accessed: 15.12.2018).

John Paul II: Allocutio ad Romanae Rotae iudices et administros coram admissos [28.01.1994]. Acta Apostolicae Sedis 86 (1994), pp. 947-952

John PAul II: Allocutio ad Rotae Romanae Praelatos, auditores, officiales et advocatos anno iudiciali ineunte [18.01.1990]. Acta Apostolicae Sedis 82 (1990), pp. $872-877$.

John Paul II: Apostolic Constitution Sacrae disciplinae leges [25.01.1983]. Available online at: http://w2.vatican.va/content/john-paul-ii/en/apost_con stitutions/documents/hf_jp-ii_apc_25011983_sacrae-disciplinae-leges.html (accessed: 15.12.2018).

John PAul II: Encyclical Letter "Veritatis splendor" [6.08.1993].

John PAul II: Letter to Families “Gratissimam Sane" [2.02.1994].

KLINGER E.: "Die dogmatische Konstitution über die Kirche Lumen gentium." In: Vierzig Jahre II. Vatikanum. Zur Wirkungsgeschichte der Konzilstexte. Ed. F.X. Bischof, S. Leimgruber. Würzburg 2004, pp. 74-97.

KRÄMER P.: Dienst und Vollmacht in der Kirche. Eine rechtstheologische Untersuchung zur Sacra Potestas-Lehre des II. Vatikanischen Konzils [Trierer Theologisches Studien, vol. 28]. Trier 1973. 
KRÄMER P.: “Su cosa si fonda la potestas sacra?” In: Antropologia, fede e diritto ecclesiale. Atti del Simposio Internazionale sugli studi canonistici di Eugenio Corecco (Lugano, 12 novembre 1994). Ed. Gerosa Libero. Milano 1995, pp. $45-56$.

Marangoni R.: La Chiesa, mistero di comunione. Il contributo di Paolo VI nell'elaborazione dell'ecclesiologia di comunione (1963-1978). Roma 2001.

May G.: "Die Kontinuität im kanonischen Recht.” Archiv für katholisches Kirchenrecht 135 (1966), pp. 52-92.

Mazzoni G.: La collegialità tra teologia e diritto canonico. Bologna 1986.

Navarrete U.: “Unità della potestas sacra e moltiplicità dei munera." In: Der Staat der Vatikanstadt, der Heilige Stuhl und die Römische Kurie. Ed. Schulz WiNfRIED. Frankfurt am Main 1999, pp. 361-389.

PAstwa A.: "The Law of the Church - the Law of Freedom." In: Religious Freedom Today. Ecumeny and Law 4 (2016), pp. 105-125.

Pastwa A.: “Libertas religiosa w kościelnym porządku prawnym.” In: „Reddite ergo, quae sunt Caesaris, Caesari et, quae sunt Dei Deo”. Księga jubileuszowa dedykowana Księdzu Profesorowi Józefowi Krukowskiemu z okazji 50-lecia pracy naukowej. Eds. M. Sitarz, P. Stanisz , H. Stawniak. Lublin 2014, pp. $175-190$.

Pastwa A.: „Przymierze miłości małżeńskiej”. Jana Pawła II idea małżeństwa kanonicznego. Katowice 2009.

Pastwa A.: "Sensus fidei fidelium. Legal and Ecumenical Reflection." In: Remaining United in Diversity. Ecumeny and Law 6 (2018), pp. 225-247.

Paul VI: Allocutio. Iis qui interfuerunt II Congressui Associationis Internationalis Canonistarum Mediolani habito [17.09.1973]. Communicationes 5 (1973), pp. $125-130$.

Paul VI: Allocutio ad Tribunalis Sacrae Romanae Rotae Decanum, Praelatos Auditores, Officiales et Advocatos, novo Litibus Iudicandis ineunte anno, de protectione iustitiae perfectiore reddenda [4.02.1977]. Acta apostolicae Sedis 69 (1977), pp. 147-153.

Pontificia Commissio Codici Iuris Canonici Recognoscendo: Principia quae Codicis Iuris Canonici recognitionem dirigant. Communicationes 2 (1969), pp. $77-100$.

Pree H.: "Zur Wandelbarkeit und Unwandelbarkeit des Ius Divinum." In: Theologia et ius canonicum. Festgabe für Heribert Heinemann zur Vollendung seines 70. Lebensjahres. Ed. Reinhardt Heinrich J.F. Essen 1995, pp. 111-135.

Ratzinger J.: The Ecclesiology of the Constitution of the Church, Vatican II, Lumen Gentium [27.02.2000]. Available online at: http://www.ewtn.com /library/curia/cdfeccl.htm (accessed: 15.12.2018).

Riedel-SpANGEnberger I.: “Gottesrecht und Menschenrecht. Zur Legitimation, Limitation und Normierung positiven kirchlichen Rechts.” In: Theologia et ius canonicum. Festgabe für Heribert Heinemann zur Vollendung seines 70. Lebensjahres. Ed. Reinhardt Heinrich J.F. Essen 1995, pp. 99-109.

Riedel-Spangenberger I.: "Ortskirche oder Teilkirche? Das vom Bischof geleitete Volk Gottes der Diözese.” In: Rechtskultur in der Diözese. Grundlagen und Perspektiven. Ed. EAdEM. Freiburg im Breisgau 2006, pp. 14-49. 
SAIER O.: „Communio” in der Lehre des Zweiten Vatikanischen Konzils. Eine rechtsbegriffliche Untersuchung. München 1973.

SobAŃsKi R.: "Charisma et norma canonica." In: Ius in vita et in missione Ecclesiae. Acta symposii internationalis Iuris Canonici occurrente $X$ anniversario promulgationis Codicis Iuris Canonici diebus 19-24 aprilis 1993 in Civitate Vaticana celebrati. Città del Vaticano 1994, pp. 75-90.

SobAŃsKi R.: “Niezmienność i historyczność prawa w Kościele: prawo Boże i prawo ludzkie." Prawo Kanoniczne 40 (1997) 1-2, pp. 23-44.

SOBAŃSKI R.: “Omnis institutio ecclesiasticarum legum ad salutem referenda sit animarum. Uwagi o zbawieniu dusz jako celu prawa kościelnego.” Ateneum Kapłańskie 134 (2000), pp. 206-218.

SyNOD OF BISHOPs: Second Extraordinary General Assembly: Ecclesia sub Verbo mysteria Christi celebrans pro salute mundi. Relatio finalis [7.12.1985), II, C, 1. Enchiridion Vaticanum, 9/1800.

Vatican Council II: Dogmatic Constitution on the Church Lumen gentium [21.11.1964].

Vatican Council II: Pastoral Constitution on the Church Gaudium et spes [7.12.1965].

Wijlens M.: “Gesetzgebung für das Volk Gottes. Vollmacht und Auftrag des Diözesanbischofs.” In: Rechtskultur in der Diözese. Grundlagen und Perspektiven. Ed. Riedel-Spangenberger I. Freiburg im Breisgau 2006, pp. 249-274.

Andrzej Pastwa

\author{
Synodalité — participation — responsabilité partagée \\ Observations sur les déterminants de l'aggiornamento \\ du droit ecclésiastique
}

\title{
Résumé
}

Dans la réalité de la communio Ecclesiae, qui se caractérise par une structure charismatique et institutionnelle unitaire, les concepts de participation et de responsabilité partagée - essentiels dans le discours juridique et canonique - sont fortement ancrées. C'est ainsi que se dévoile l'horizon de la problèmatique, dont l'étude - en termes de triade parue dans l' intitulé: synodalité — participation — responsabilité partagée — ne perdra jamais de sa pertinence. Surtout, l'idée de "synodalité » - convenablement reconnue comme sacra potestas d'origine sacramentelle (aspect ontologique), gagnant le dynamisme de libertas sacra grâce aux charismes du Saint-Esprit (aspect existentiel-dynamique) - conduit à l'inséparabilité de ses aspects : personnel et synodal.

Ainsi, dans la tentative d'éclairer le déterminant de l'«aggiornamento» de la loi ecclésiastique, il était convenable, d'une part, de se référer systématiquement à l'essence de l'idée de communio hierarchica, selon laquelle le Christ fait des serviteurs choisis participants à son pouvoir par une fonction dont l'exécution reste toujours une diaconie dans la communauté de foi; d'autre part, en référence à la compréhension contemporaine de 
communio fidelium - l'axe de la réflexion scientifique devrait être le phénomène des charismes lié à la communion et à la création - ces dons de l'Esprit Saint, suscitant chez les prêtres la responsabilité partagée et synodale pour le bien de toute la communauté ecclésiale. Dans les deux cas - sans perdre de vue la vérité évidente que dans la structure sacramentelle de l'Église (communio) les dons hiérarchiques et charismatiques cö̈ncident dans le ministère de l'évêque qui actualise - conformément à la logique de l'aggiormamento de Vatican II et aux principes ecclésiologiques: la collégialité, la synodalité et la subsidiarité — la plénitude du ministère du Christ : Prophète, Prêtre et Roi.

Mots clés : ecclésiologie, principe de communio, synodalité, participation, responsabilité partagée, aggiornamento du droit ecclésiastique

Andrzej Pastwa

\section{Sinodalità - partecipazione - responsabilità condivisa \\ Osservazioni sulle determinanti dell'aggiornamento del diritto ecclesiastico}

\section{Sommario}

Nella realtà della communio Ecclesiae, che si caratterizza per una struttura carismatica e istituzionale unitaria, i concetti di partecipazione e di responsabilità condivisa - essenziali nel discorso giuridico e canonico, sono fortemente ancorati. Si svela così l'orizzonte della questione, il cui studio - nei termini della triade apparsa nel titolo: sinodalità - partecipazione - responsabilità condivisa - non perderà mai la sua rilevanza. È importante sottolineare che l'idea di "sinodalità" - adeguatamente riconosciuta come sacra potestas di origine sacramentale (aspetto ontologico), guadagnando il dinamismo di libertas sacra grazie ai carismi dello Spirito Santo (aspetto esistenziale e dinamico) —conduce all'inseparabilità dei suoi aspetti: personale e sinodale.

Pertanto, nel tentativo compiuto in questo studio di illuminare le determinanti dell' "aggiornamento" del diritto ecclesiastico, è stato opportuno, da un lato, riferirsi sistematicamente all'essenza dell'idea di communio hierarchica, secondo la quale Cristo rende i servi eletti partecipi del suo potere mediante un ufficio il cui adempimento resta sempre una diaconia nella comunità di fede; d'altra parte, in riferimento alla concezione contemporanea di communio fidelium - asse della riflessione scientifica dovrebbe essere il fenomeno dei carismi collegato con la comunione e la creazione - questi doni dello Spirito Santo, suscitando la responsabilità condivisa e sinodale per il bene dell'intera comunità ecclesiale nel popolo sacerdotale. In entrambi i casi - senza perdere di vista l'ovvia verità che nella struttura sacramentale della Chiesa (communio) sia i doni gerarchici che quelli carismatici coincidono nel ministero del vescovo che attua - secondo la logica dell'aggiormamento esposta dal Vaticano II e dei principi ecclesiologici conciliari: la collegialità, la sinodalità e la sussidiarietà — la pienezza del ministero di Cristo: Profeta, Sacerdote e Re.

Parole chiave: ecclesiologia, principio di communio, sinodalità, partecipazione, responsabilità condivisa, aggiornamento del diritto ecclesiastico 